\title{
STEAM DALAM PEMBUATAN PAKAN UNTUK KOMODITAS AKUAKULTUR
}

\author{
Sukarman \\ Balai Riset Budidaya Ikan Hias \\ Jl. Perikanan No. 13 Pancoran Mas, Depok \\ E-mail: carman_gbg@ yahoo.com
}

\begin{abstract}
ABSTRAK
Kualitas fisik pakan (pelet) untuk hewan akuakultur sangat penting, karena akan dimasukkan ke dalam air dan diharapkan tidak banyak mencemari lingkungan. Salah satu faktor yang berpengaruh dalam menjaga kualitas fisik pakan adalah penambahan dan pengaturan steam pada saat proses pembuatan pelet. Steam adalah aliran gas yang dihasilkan oleh air pada saat mendidih. Steam dibagi menjadi 3 jenis yaitu steam basah, saturated steam, dan superheated steam. Steam yang digunakan dalam proses pembuatan pelet adalah saturated steam. Pengaruh penambahan steam pada kualitas pelet bisa mencapai $20 \%$ Penambahan steam dengan jumlah dan kualitas yang tepat akan menghasilkan pelet berkualitas. Sedangkan jika pengaturan dan penambahannya tidak tepat, maka kualitas fisik pelet akan rendah dan kemungkinan bisa merusak kandungan nutrisi seperti vitamin dan protein. Penambahan steam yang benar bisa dilakukan di dalam kondisioner dengan mengatur retention time, sudut kemiringan paddle conditioner, kecepatan putaran bearing dan menjaga kualitas steam dari mesin boiler sampai dengan kondisioner.
\end{abstract}

KATAKUNCl: kondisioner, kualitas, pelet, steam

\section{PENDAHULUAN}

Kualitas fisik pakan untuk hewan akuakultur (udang dan ikan) sangatlah penting, hal ini dimaksudkan untuk mencegah terjadinya penurunan kualitas air saat pemberian pakan yang sering berlebih. Kualitas fisik pakan sendiri dipengaruhi oleh banyak faktor, di antaranya adalah bahan baku, formulasi pakan, proses pembuatan, dan spesifikasi mesin yang digunakan. Pada kenyataannya seringkali ditemukan bahwa pakan buatan sendiri kualitasnya lebih rendah dibandingkan dengan pakan buatan pabrik, walaupun sudah menggunakan bahan baku dan formulasi yang sama. Hal ini bisa saja terjadi karena proses pembuatan pakan yang kurang tepat akan menghasilkan pakan yang tidak optimal untuk pertumbuhan ikan.
Sebagai contoh, tingkat kematangan pati jagung sangat mempengaruhi nilai kecernaan oleh ikan. Zhang \& Cremer (1997), menjelaskan bahwa perebusan jagung yang tepat mampu meningkatkan kecernaan ikan lele dan nila dari 26\%dan 45\%menjadi sekitar 58\%dan 72\%

Salah satu tahapan pembuatan pakan yang berpengaruh terhadap tingkat kematangan bahan adalah proses pelleting, yaitu merubah bentuk dari tepung menjadi pelet. Pada proses inilah terjadi pematangan bahan yang berakibat terjadinya gelatinisasi sehingga bahan bisa lengket dan kuat. Namun demikian proses ini tidak akan sempurna tanpa menambahkan panas dan air ke dalam mesin. Penambahan panas dan air ini harus merata ke semua bahan, sehingga kualitas pakan yang dihasilkan bisa homogen. Hal tersebut biasa dilakukan dengan penambahan steam sebelum bahan memasuki mesin pelet. Pengetahuan ini jarang dimiliki oleh praktisi pakan yang menggunakan mesin berskala kecil. Biasanya mesin-mesin pelet tradisional dan berskala kecil jarang sekali dilengkapi alat yang mampu memproduksi steam. Tulisan ini diharapkan mampu menginspirasi para praktisi untuk melakukan modifikasi mesin pelet, dan mengenalkan penggunaan steam dalam proses pembuatan pakan ikan. Karena dengan cara ini dapat memberikan beberapa keuntungan baik dari sisi kecernaan, nutrisi, produksi maupun biaya listrik. Peningkatan kualitas pakan dari praktisi dan pabrik skala kecil diharapkan akan mampu mengurangi monopoli dan dominasi pabrik besar yang selalu menjual pakan dengan harga yang relatif mahal.

\section{PENGERTIAN STEAM}

Steam adalah aliran gas panas yang dihasilkan oleh air pada saat mendidih (Smith, 1997). Pengertian steam dan uap air hampir sama, perbedaannya ada pada kandungan energi (panas), tekanan dan kandungan airnya. Secara umum bisa disebutkan bahwa steam merupakan bagian dari uap air, tetapi tidak semua uap air bisa dikatagorikan sebagai steam. Tidak semua steam juga bisa dipakai. Untuk memastikan steam bisa dipakai dalam proses pembuatan pakan akuakultur khususnya pelet tenggelam maka perlu ada pengetahuan dasar mengenai karasteristik steam. Steam dikelompokkan menjadi 3 macam yaitu: steam 
basah, saturated steam (uap jenuh), dan superheated steam (uap kelewat jenuh). Steam basah terdiri atas air ( $20 \% \mathrm{~A}$ dan steam (80\%) dengan kandungan energi 956 BTU/LB, sedangkan saturated dan superheated steam merupakan murni uap air dengan kandungan energi berturut-turut 1.150 BTU/LB dan 1.384 BTU/LB. Steam basah dan saturated steam terbentuk pada suhu $150^{\circ} \mathrm{C}$ sampai $300^{\circ} \mathrm{C}$. Bila terjadi penurunan suhu menjadi lebih rendah dari $100^{\circ} \mathrm{C}$ maka steam basah akan terbawa jatuh bersama air. Fleck (2002) mengatakan bahwa steam basah selalu menghasilkan butiran air pada suhu ebullition. Sedangkan ketika saturated steam mendingin akan terjadi proses pengembunan. Berbeda pula dengan superheated steam, terbentuk pada suhu $700^{\circ} \mathrm{C}$ dan ketika suhu turun maka superheated steam akan kembali berubah menjadi saturated steam tahap awal.

Di antara ketiga jenis steam, yang biasa digunakan dalam proses pembuatan pakan akuakultur adalah saturated steam. Steam basah jika dipakai akan menghasilkan pakan yang kurang baik. Sedangkan superheated steam biasanya dipakai untuk pembangkit energi. Proses penguapan air menjadi steam dapat dilihat pada Gambar 1 , sedangkan kurva karakteristik pembentukan steam diilustrasikan pada Gambar 2.

Beberapa keunggulan penggunaan steam dalam pembuatan pelet ikan dibandingkan dengan sumber panas lainnya adalah: ketersediaan air yang berlimpah, lebih aman, butuh temperatur yang rendah, air dapat menyerap energi yang lebih besar, steam akan terkondensasi pada suhu yang konstan, serta hubungan antara tekanan dan temperatur steam mudah dipahami melalui steam table.

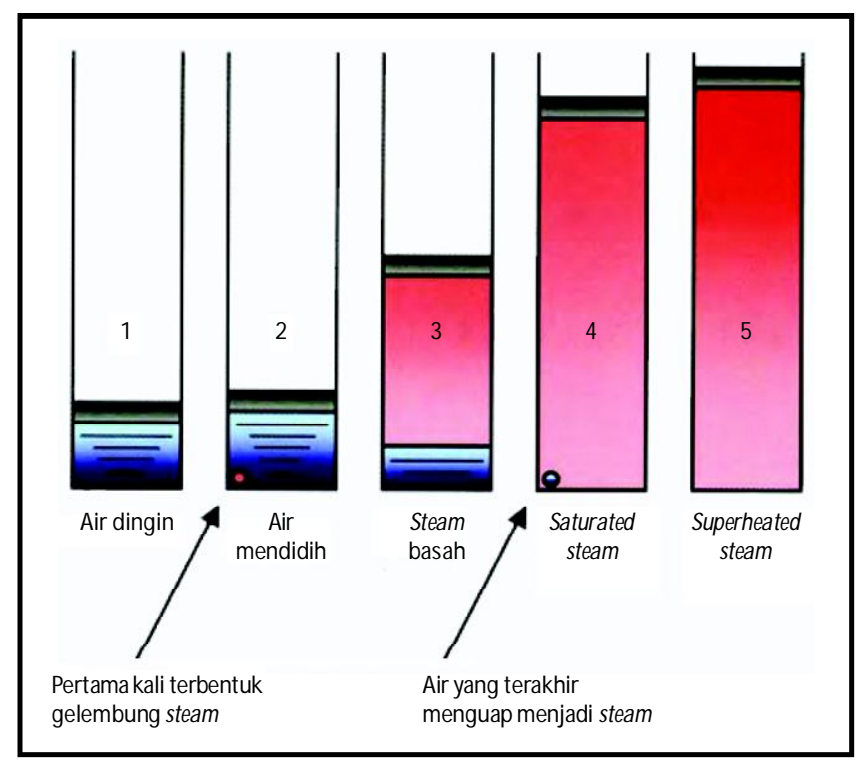

Gambar 1. Proses penguapan air menjadi steam pada tekanan yang sama

\section{FUNGSI STEAM}

Pada saat proses pembuatan pelet ada tahapan di mana bahan baku pakan harus dikondisikan pada suhu dan kadar air tertentu. Tahapan ini terjadi di dalam alat yang disebut conditioner (kondisioner), sedangkan prosesnya dinamakan conditioning. Conditioning sangat berpengaruh terhadap kualitas pelet yang dihasilkan. Jika suhu terlalu tinggi akan merusak kandungan vitamin dan protein pakan, tetapi jika suhu terlalu rendah proses gelatinisasi tidak sempurna sehingga kualitas fisik pelet akan mudah pecah. Sedangkan jika kadar air bahan terlalu tinggi pelet yang dihasilkan tidak stabil, tetapi jika kadar air terlalu rendah proses produksi akan berjalan sangat lambat. Untuk menghindari hal-hal tersebut maka diperlukan penambahan steam ke dalam kondisioner (Tabel 1).

Penambahan steam ini sama dengan menambahkan air dan suhu untuk mematangkan beberapa bahan secara bersama-sama (Smith, 2003). Pengaturan banyaknya steam bisa dilakukan berdasarkan tekanan, dan kecepatan laju bahan baku di dalam kondisioner.

Keuntungan lain penggunaan steam dalam pembuatan pelet akuakultur adalah meningkatkan produktivitas antara lain melalui penghematan energi listrik, mempercepat terjadinya gelatinisasi, menghindari kehilangan berat akibat penyusutan, mengurangi biaya produksi, meningkatkan daya rekat antar bahan, mengurangi bakteri patogen, pakan jadi lebih awet dan meningkatkan kualitas. Menurut Nef (2002), penambahan steam dalam proses pembuatan pelet lebih menguntungkan dibandingkan penambahan air dingin dan air hangat. Schofield (2005) menambahkan bahwa jika air saja yang dibutuhkan dalam proses pembuatan pelet, maka penggunaan selang air yang ditempelkan ke mesin akan lebih ekonomis dibandingkan steam. Sebaliknya jika panas saja yang dibutuhkan maka penggunaan gas panas langsung dari hasil pembakaran juga bisa lebih efektif. Namun yang dibutuhkan adalah panas dan air yang bisa tepat mengenai permukaan seluruh bahan, sehingga hanya steam saja yang praktis digunakan untuk hal ini (Tabel 2).

Pembuatan pelet secara tradisional biasanya tidak menggunakan steam, tetapi perlu diketahui bahwa steam sangat berpengaruh terhadap kualitas pakan, dari sisi kecernaan nutrisi maupun fisik. Faktor lain yang berpengaruh terhadap kualitas pelet menurut Reimer (1992), antara lain formulasi, spesifikasi die, pendinginan (cooling), dan grinding (Gambar 3).

Formulasi dengan bahan berlemak tinggi akan mempercepat proses pembuatan pelet, tetapi kualitas peletnya menurun. Sebaliknya bahan-bahan yang 


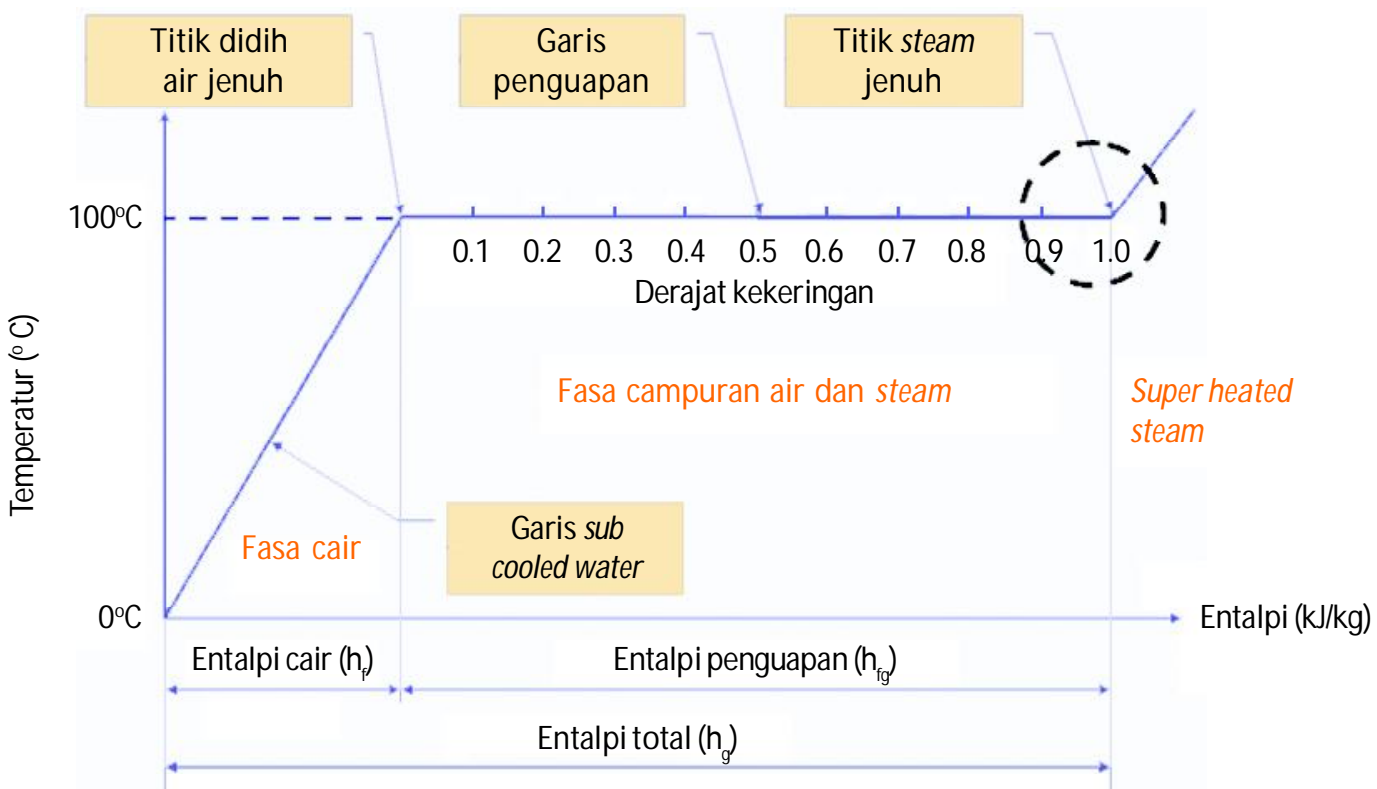

Gambar 2. Kurva karakteristik pembentukan steam pada tekanan atmosferik

Tabel 1. Kisaran perubahan kestabilan vitamin pada proses pelleting (\%)

\begin{tabular}{lcccc}
\hline \multirow{2}{*}{ Vitamin } & \multicolumn{4}{c}{ Suhu ('F) } \\
\cline { 2 - 5 } & $\mathbf{1 7 0}$ & $\mathbf{1 8 0}$ & $\mathbf{1 9 0}$ & $\mathbf{2 0 0}$ \\
\hline A beadlet & $90-100$ & $90-100$ & $90-95$ & $85-90$ \\
D3 beadlet & $90-100$ & $90-100$ & $90-95$ & $85-90$ \\
E actetate & $90-100$ & $90-100$ & $90-95$ & $80-90$ \\
E spray dry & $90-100$ & $90-100$ & $90-95$ & $85-90$ \\
K (menadione sodium bisulphite) & $50-60$ & $40-50$ & $40-50$ & $35-40$ \\
K (menadione nicotinamide bisulphite) & $80-90$ & $70-80$ & $65-75$ & $65-75$ \\
Thiamin monohydrate & $90-100$ & $90-100$ & $90-95$ & $85-90$ \\
Thiamin HCL & $90-100$ & $85-95$ & $85-95$ & $70-80$ \\
Riboflavin & $90-100$ & $90-100$ & $90-95$ & $85-90$ \\
Pyridoxine & $90-100$ & $90-100$ & $90-95$ & $85-90$ \\
Vitamin B12 & $90-100$ & $80-90$ & $70-85$ & $60-80$ \\
Ca pantothenate & $90-100$ & $90-100$ & $90-95$ & $85-90$ \\
Niacin & $90-100$ & $90-100$ & $90-95$ & $85-90$ \\
Niacinamide & $90-100$ & $90-100$ & $90-95$ & $85-90$ \\
Folic acid & $90-100$ & $85-90$ & $80-90$ & $70-80$ \\
Biotin & $90-100$ & $90-100$ & $90-95$ & $85-90$ \\
Vitamin C ethycellulose & $50-80$ & $40-70$ & $30-60$ & $20-40$ \\
Vitamin C phosphorylated & $90-100$ & $90-100$ & $90-95$ & $90-95$ \\
\hline
\end{tabular}

Sumber: McDowell (2005)

Tabel 2. Perbandingan penggunaan air dengan steam pada proses pembuatan pelet

\begin{tabular}{lccc}
\hline \multicolumn{1}{c}{ Bahan pengaruh } & Air dingin & Air hangat & Steam \\
\hline Hasil produksi & Meningkat 15\%20\% & Meningkat 20\%30\% & Meningkat 50\%100\% \\
Konsumsi energi listrik & Menurun 5\% 10\% & Menurun 10\% 25\% & Menurun 30\% 100\% \\
Kualitas pelet & Tidak meningkat & Meningkat sedikit & Meningkat signifikan \\
\hline
\end{tabular}

Sumber: Nef (2002) 


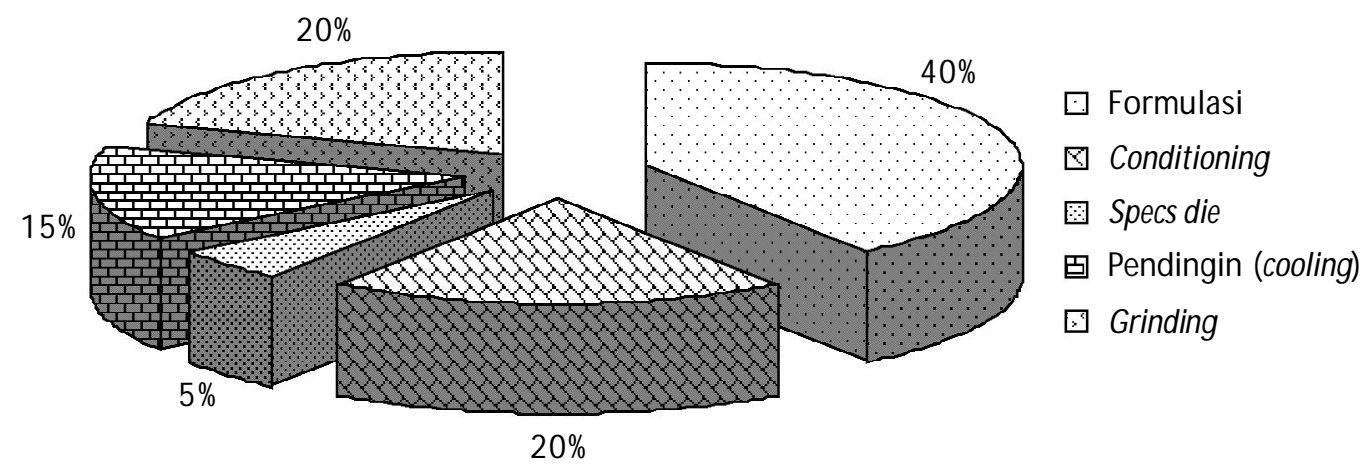

Gambar 3. Faktor-faktor yang mempengaruhi kualitas pelet

mengandung pati tinggi seperti terigu akan meningkatkan kualitas pelet. Spesifikasi mesin pelet terutama die juga mempunyai pengaruh yang cukup nyata. Die merupakan salah satu bagian dari mesin pelet, berbentuk seperti roda, berlubang-lubang dengan diameter lubang dan panjang tertentu. Perbandingan diameter lubang die dengan panjang lubang inilah yang berpengaruh terhadap kualitas pelet. Besarnya pengaruh conditioning terhadap kualitas pelet mencapai $20 \%$ sehingga pengaturan conditioning dan penggunaan kualitas steam yang tepat juga dirasa penting.

\section{PENGATURAN STEAM DAN CONDITIONING}

Steam yang bisa digunakan dalam proses pembuatan pakan mempunyai beberapa kriteria. Kriteria tersebut adalah jumlahnya mencukupi, kualitasnya bagus; diberikan pada suhu dan tekanan yang konstan (stabil), bebas dari udara (gas lain) dan kondesat, bersih, dan kering. Jumlah dan pengaturan steam ini bisa diatur di dalam kondisioner. Sedangkan hal yang berhubungan dengan kualitas steam diatur mulai dari mesin boiler sampai dengan kondisioner. Kualitas steam sendiri yaitu derajat atau kandungan air dalam steam, dinyatakan dalam bentuk dryness fraction atau derajat kekeringan.

Prinsip produksi steam pada mesin boiler pada dasarnya sama dengan ketika merebus air (Gambar 4). Perbedaannya ada pada jumlah dan kontrol pengeluaran steam. Steam yang terbentuk pada mesin boiler disalurkan melalui pipapipa yang dilapisi penahan panas agar energi (kalor) tidak banyak terbuang. Meski demikian di dalam pipa-pipa menuju kondisioner akan terjadi pembuangan kondensat akibat penurunan suhu. Pipa tersebut juga tidak boleh bocor, karena akan mengurangi jumlah steam yang tersedia. Hal terpenting yang harus dilakukan adalah pengaturan jumlah steam yang masuk ke dalam kondisioner dan lamanya bahan baku pakan terkena steam (retention time). Retention time steam berhubungan dengan kapasitas kondisioner, kecepatan putaran bearing dan kemiringan paddle conditioner. Menurut Koch (2008), retention time (Rt) dapat diperoleh dari jumlah bahan baku yang mampu ditampung oleh kondisioner (Cf) dibagi dengan rata-rata produksi pelet $(\mathrm{P})$, dan dapat dirumuskan sebagai berikut:

$$
\mathrm{Rt}=\frac{\mathrm{Cf}}{\mathrm{P}}
$$

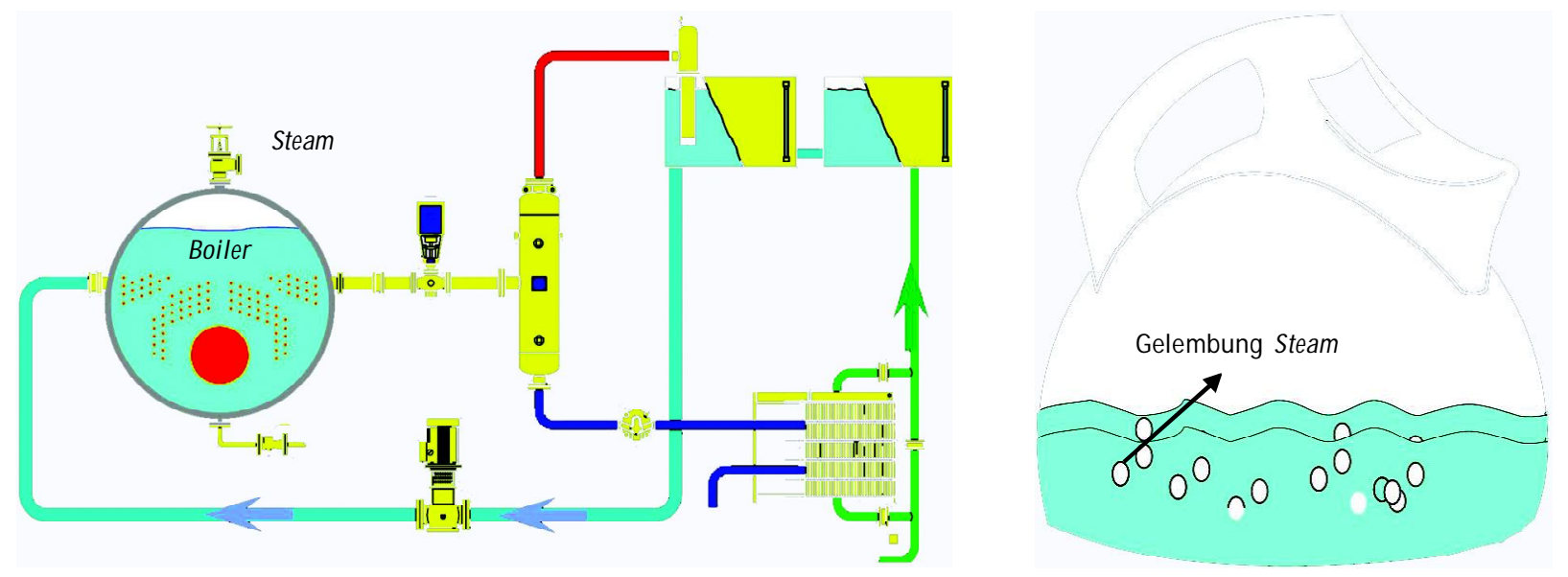

Gambar 4. Mesin boiler dan ketel (sama-sama mampu menghasilkan steam) 
Semakin lama bahan baku pakan di dalam kondisioner semakin baik kualitas pelet yang dihasilkan. Umumnya industri pakan ikan menggunakan 2 atau 3 kondisioner dalam 1 mesin pelet (Gambar 5). Hal tersebut dimaksudkan agar pakan yang dihasilkan tidak banyak yang berbentuk tepung, hal ini selaras dengan pendapat Winowiski (1995) bahwa pakan yang berbentuk tepung biasanya akan terbuang jika sampai di dasar kolam. Terlebih pada pakan udang, nilai Pellet Durability Index (PDI) harus tinggi karena udang makan sangat lambat. Retention time sendiri dipengaruhi oleh kecepatan putaran bearing conditioner dan paddle. Sudut kemiringan paddle diatur mulai dari $0^{\circ}, 15^{\circ}, 45^{\circ}, 75^{\circ}$, sampai dengan $90^{\circ}$. Semakin tinggi derajat kemiringan paddle, laju bahan baku dalam kondisioner semakin lambat, dan sebaliknya semakin rendah kemiringannya semakin cepat bahan baku melewati kondisioner. Untuk menyeimbangkan antara kecepatan produksi dan kualitas pelet sebaiknya kemiringan paddle diatur berkisar antara $45^{\circ}-75^{\circ}$. Atau bisa dengan cara penambahan jumlah kondisioner. Sementara kecepatan putaran bearing selain mempengaruhi retention time juga berpengaruh terhadap pencampuran bahan baku dengan steam (Gambar 6). Jika kecepatan terlalu rendah maka steam tidak akan bercampur dengan bahan baku, tetapi jika kecepatan bearing terlalu cepat maka bahan baku akan berada di bagian luar kondisioner sedangkan steam akan ditengah-tengah. Akibatnya steam dan bahan baku tidak tercampur secara merata dan proses gelatinisasi tidak akan sempurna.

Faktor lain yang mempengaruhi proses gelatinisasi pada kondisioner adalah ukuran partikel dari bahan baku. Semakin kecil ukuran bahan baku semakin besar luas permukaan bahan. Sehingga bahan akan lebih mudah tergelatinisasi, serta akan menghasilkan pelet yang lebih kokoh. Indikasi jika ukuran bahan baku terlalu besar adalah
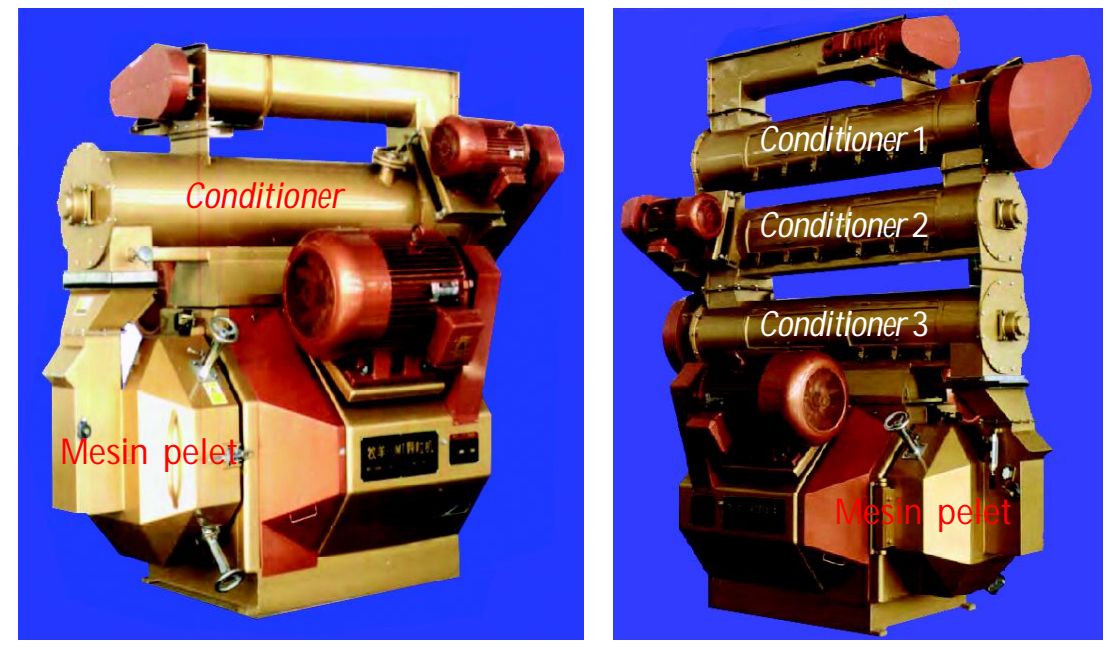

Gambar 5. Mesin pelet 1 kondisioner (kiri), mesin pelet 3 kondisioner (kanan)

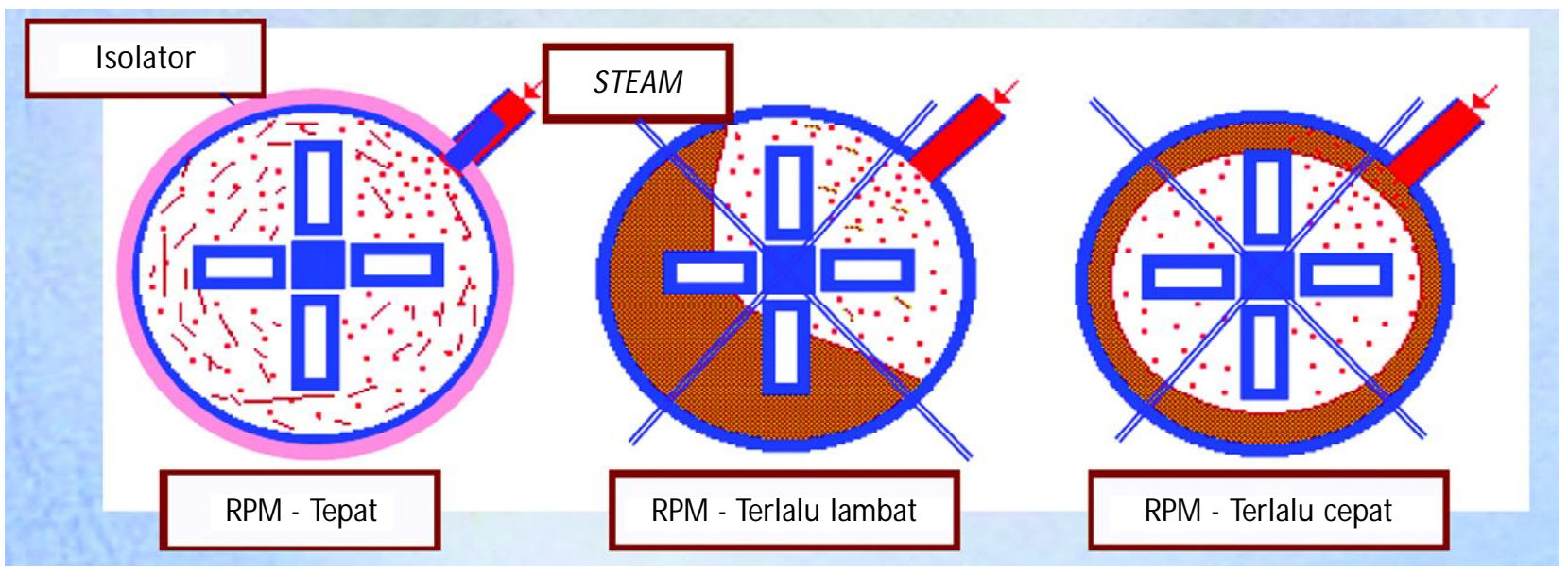

Gambar 6. Ilustrasi pengaruh kecepatan bearing terhadap penetrasi steam dalam kondisioner 


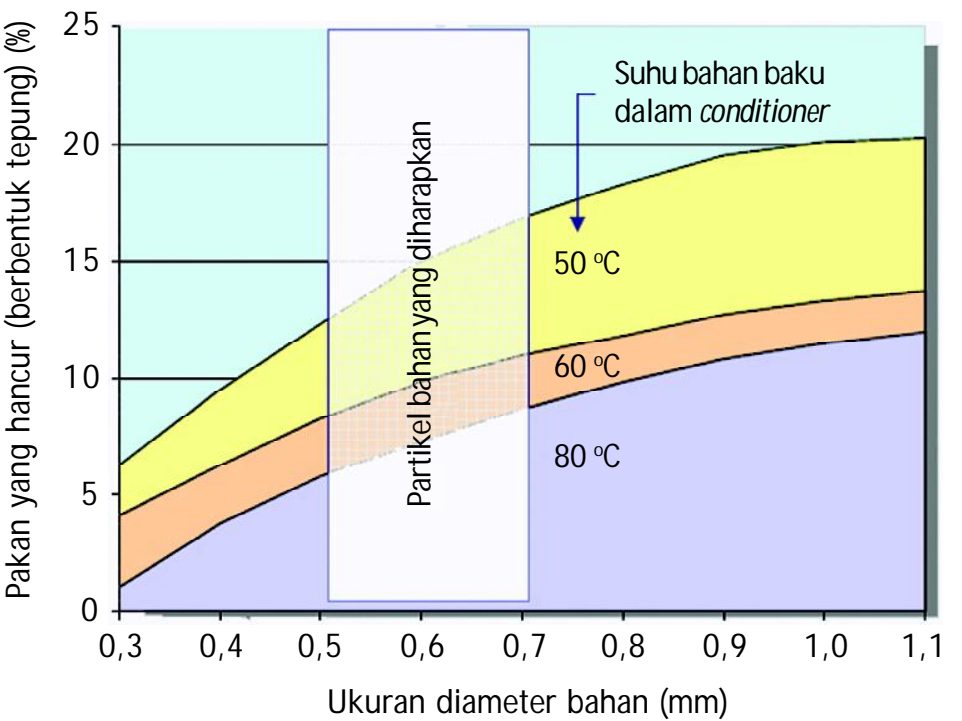

Gambar 7. Hubungan partikel baku, suhu konditioner, dan kualitas pelet

banyaknya pakan yang berbentuk tepung. Jika ukuran partikel bahan besar kemudian diproses pada suhu rendah maka akan semakin banyak tepung yang terbentuk.

Hubungan antara partikel bahan baku, suhu dalam kondisioner, dan kualitas pelet menurut Bilgiani (2008), dapat dilihat pada Gambar 7. Selain meningkatkan kualitas pelet, ukuran bahan yang kecil akan menaikkan kapasitas produksi, density pakan dan membuat mesin pelet menjadi lebih awet.

Namun demikian, keberhasilan proses gelatinisasi perlu didukung oleh kualitas steam yang bagus. Steam basah tidak mudah terserap dalam bahan yang ukurannya kecil sekalipun. Karena steam basah banyak mengandung air sehingga akan membasahi permukaan bahan. Sehingga bahan akan bertambah licin. Berbeda dengan saturated steam, akan mudah masuk ke dalam bahan dan menjadikan bahan seperti plastik. Pada akhirnya pelet yang terbentuk akan lebih lengket.

\section{PENUTUP}

Pemahaman mengenai proses pembuatan pakan terutama pakan pelet harus dikuasai. Khususnya penggunaan steam sebaiknya dimengerti agar pakan yang dibuat oleh para praktisi meningkat kualitasnya mendekati pakan dari pabrik. Harapan ke depannya, kemampuan tersebut bisa menjadi pemicu penurunan harga pakan karena kompetisi yang sehat.

\section{DAFTAR ACUAN}

Anonymous. 2001. Pelleting Machine and Process Control. Swiss Institute of Feed Technology.
Anonymous. 2005. Dasar-Dasar Steam. PT Spirax Sarco Indonesia.

Bigliani, G. 2008. Steam Conditioning and Moisture Control for Aquaculture Feed. 16 th Annual ASAIM South East Asia Feed Technology and Nutrition Workshop.

Fleck, D. 2002. Liquid and Steam Addition. Swiss Institute of Feed Technology.

Koch, K.B. 2008. Pelleting : A Rievew of the Process and a New Ingredient. $16^{\text {th }}$ Annual ASAIM South East Asia Feed Technology and Nutrition Workshop.

McDowell, L.R. 2005. Optimum Vitamin Nutrition for Poultry. Department of Animal Sciences, University of Florida, Gainesville, Florida 32611, USA.

Nef, E. 2002. Technology of Pelleting. Swiss Institute of Feed Technology.

Reimer, L. 1992. Conditioning. Proc. Northern Crops Institute Feed Mill Management and Feed Manufacturing Technology. Short Course. California Pellet Mill Co. Crawfordsville, I.N., p. 7.

Schofield, E.K. 2005. Feed Manufacturing Technology. American Feed Industry Association, Inc.

Schmittou, H.R; Chremer, M.C., \& Zhang, J. 1997. Principle and Practice of High Density Fish Culture in Low Volume Cages. (Copyright 2004) American Soybean Meal Assosiation.

Smith, G. 1997. Steam for Pelleting in Feedmill. Spirax Sarco Pty Limeted.

Smith, G. 2003. Steam: The Delicate Balance Heat and Temperature. Feed Technology, 7(7).

Winowiski, T.S. 1995. Pellet Quality in Animal Feed. Feed Technology 21. 